\title{
Studying the Role of Positive Reinforcement for Motivation to Learn the English Language at Secondary Level in Pakistan
}

\author{
Muhammad Safdar Bhatti ${ }^{1}$, Asif Iqbal ${ }^{2}$, Rafia Mukhtar ${ }^{3}$, Shaista Noreen ${ }^{4}$, Zahida Javed ${ }^{5}$ \\ ${ }^{1,4}$ The Islamia University of Bahawalpur. Pakistan \\ ${ }^{2}$ University of Education Lahore, Faisalabad Campus. Pakistan \\ ${ }^{3}$ Workers Welfare School (Girls), Bahawalpur. Pakistan \\ ${ }^{5}$ University of Education Lahore, Joharabad Campus. Pakistan \\ safdarbhatti2001@gmail.com
}

\section{ARTICLE HISTORY \\ Received : 2021-01-13 \\ Revised : 2021-02-15 \\ Accepted : 2021-02-18}

\section{KEYWORDS}

Motivation

Reinforcement

Classroom

Spotlighted

Lingua Franca

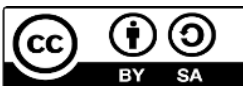

\begin{abstract}
English is being used all over the world as an international language. It is a Lingua Franca that enjoys a supreme status in society. Learners have to wrestle with new vocabulary, rules of grammar, pronunciation, and more. So, the current study explores the students' motivation and the perceptions of English teachers about positive reinforcement in an English language classroom. Motivation and attitudes in learning a language in the classroom are very important and may make language courses more stimulating. The study contained a quantitative paradigm of control and experimental group as the research design. One hundred students and thirty teachers were selected using a simple random sampling technique. The data were collected using a closeended self-developed questionnaire of 30 items with five main indicators subdivided into six indicators. The collected data was analysed in SPSS. The results demonstrated that Pakistani students were motivated in learning the English language and have shown a positive attitude towards using reinforcement in the classrooms. The study also spotlighted that if the motivation is used efficiently in the classroom, it will be a high-ranking tool for language learning. The recommendations and findings of this study should be taken into careful consideration, and steps should be taken to implement them in Pakistani English language classrooms.
\end{abstract}

\section{Introduction}

Reinforcement is the most effective strategy that the majority of teachers familiar with in managing English classrooms. Among all strategies, reinforcement of praise is best suited in social interaction. Praise is the tool for instructions and increases the academic and social behavior of learners. The students view the care provided via praise as a motivational and teaching technique (Rachman \& Nur, 2017). Language is the medium to transform our thoughts and feelings into another human beings. Through language, we can get and transfer the knowledge of culture, religion, values, traditions, and science. Motivation, attitudes, and set of beliefs about learning the language are among the determining factors that can influence the efficiency of the students in language classes (Oroujlou \& Vahedi, 2011). Therefore, the instructors and educators should be careful in taking these factors into account. There are many languages globally, but a few have specific and international recognition in the world. The English language is one of them, and it is the need of the present day. It is an advanced and international language.

All the scientific, mathematical \& and industrial knowledge is in it. It is necessary to acquire and learn this language. According to studies, reinforcement helps as motivational forces in English language learning (Khaliq, Douna, \& Ahsan, 2016). There are many types of reinforcement like contact, gestures, verbal, and proximity. Positive reinforcements are when teachers use very good, good, friendly, well done, smiling, thumb up, applauding students, and sitting close to pupils (Pratiwi, Sudirman, \& Adnyani, 2018). One cannot get knowledge about the world without acquiring the command of the English language. Now the question is that how can one acquire the English language easily? A teacher must make learning the language very easy. There are many techniques to make this process practical. First of all, to learn anything or perform any task, reinforcement plays an important role. According to Dornyei (1998), 
positive reinforcement with the help of motivational tools plays a constructive role and helps students in setting beliefs, cognition, and values in the achievement process. According to Sahana (2012), some students find some subjects difficult and require frequent rewards, and if the school subject or project does not provide them any reward, they show low performance. As Henderlang and Lepper (2000) described, at the same time, praise not only motives the student but also enhances self-confidence in the students because students like to remain engaged in those works in which they are appreciated. So through this research study, the researchers want to know the role of positive reinforcement for learning the English language at the primary level. It is an insight into the positive reinforcement for learning the English language at the secondary level.

It was found that pupils show positive responses after implementing reinforcement in classrooms in the form of teachers' praise (Rachman \& Nur, 2017). The researchers also want to know how positive reinforcement enhances the learning ability of the students and how positive reinforcement stimulates the learner for learning. The current study attempts to search for the most appropriate, fruitful, and inspirational way to teach the English language in secondary schools. It finds out positive reinforcement for improving English language skills and the teachers' perceptions regarding motivation. The hypotheses of the study were:

The students perform well through positive reinforcement by using motivational tools (reward, praise, competition, a star, some other interesting activities compared to those who are taught).

1) Positive reinforcement enhances students' performance in learning the English language.

2) There is a difference between the scores of the control \& experimental groups.

Any learning cannot be acquired without motivation. Motivation works as a lubricant for learning. Much work has been done on this topic, but, indeed, there is always room for improvement in every field. This study throws light on the importance of positive reinforcement and motivation for learning. In this study, the researchers point out the different reinforcement techniques and set recommendations for language teachers. This study showed the importance of positive reinforcement for learning the English language at the primary level.

\section{Literature Review}

During the $20^{\text {th }}$ century, much work has been done on motivation in the educational field. An educational psychologist suggests many ways to motivate students for learning. Many researchers have also researched "the role of positive reinforcement. According to Evans and Tragant (2020), there is a positive relationship between dropout and demotivation among adult learners. The students are demotivated by external issues like poor speaking skills, teaching practice, and a low level of fluency in learning a language. This notion leads to a justification that learners with demotivation may lose their grades in exams (Vibulphol, 2016). On the other hand, positive motivation influences learners' performance rapidly (Ng \& Ng, 2015)

The teachers should use more motivational techniques to make their students attentive in the class". For this research, the working researcher observed and evaluated the common behavior of the language teachers and the casual environment of language classrooms. Researchers observed that language teachers often teach the grammar or rules of language in a typical style without creating interest or motivating the learners. According to Christir and Afzaal (2005), in Pakistan, the dependency of old tradition methods and minimal use of modern techniques are the parts of the education system. Students take these rules as a burden, and they feel bore. Such teachings of language rules badly fail to catch their attention. The factor of positive reinforcement in learning a language increases lessons (Krishna \& Pathan, 2013). The learners who got vocabulary learning strategies negatively (Tanaka, 2017). This situation may lead them to lose both integrative and instrumental motivational techniques (Bahramy \& Araghi, 2013). Further, As Ahmed and Mahmood (2010) say, traditional instructions are less effective in a teaching-learning atmosphere than cooperative learning. As a result, students do not show good performance at the end. If some students acquire the rules of grammar of the English language, but they cannot communicate or (interact) transfer their ideas with others. Oxford and Shearin (1994) explored an important impact of motivation in students' achievement scores. Motivation determined the learners' level of engagement in learning a language. Motivation has many special effects on the learning behavior of students. It directs specific goals to increase motivation among students, which affects their achievement and improves the cognitive process.

Dörnyei and Ushioda (2013) have expressively defined motivation. They claimed that motivation originates from the Latin verb "mover," which means to move. Motivation impacts performing actions and make choices. The word motivation has two terms: magnitude and direction. Dörnyei (2001) projected that learners' learning is based on teachers who motivate students by employing pleasant approaches. This is done by making the classroom atmosphere of classrooms friendly and relaxed.

\subsection{Types of Motivation}

According to Iqbal (2011), there are two types of motivation. Intrinsic and extrinsic motivation. The most basic distinction is between intrinsic motivation, 
which refers to doing something because it is inherently interesting or enjoyable, and extrinsic motivation refers to doing something because it leads to a separable outcome.

\subsection{Sources of Motivation}

This observation compels the researcher to inquire why students are not competent in the English language. The researcher wants to know that is there any role of motivation or positive reinforcement here? As Larasati (2018) described, student-centered approach results in the superior performance of slow learners. The correlation between communication and student-centered approaches Positive. These approaches create learning by doing situations. The scholars may improve their speaking skills through tasks that are devised with their needs. It was developed in integrating the multiple dispositional, content, and need theories in the single workable motivational model (Leonard, Beauvais, \& Scholl,1955). There are five sources of motivation.

\subsection{Intrinsic Process Motivation}

Individuals primarily motivated intrinsic process to engage in activities which they consider enjoyable of fun. It is the performance of the tasks itself, rather than outcomes or results of the task that provide satisfaction" (Leonard, Beauvais, \& Scholl, 1999).

\subsection{External or Self-Concept Motivation}

It the attitude maintained by the use of external rewards or incentives like fame, praise, and money (Cherry, 2021). Self-concept motivation is extremely based on when the individual is primarily otherdirected. The concept of this kind of motivation is resulting from accepting the expectations of the reference group. While the idea of self-concept motivation is based on inner directions of the mind (Leonard, Beauvais, \& Scholl,1999).

\section{Method}

The current study was experimental with experimental and control group designs. Also, a questionnaire was filled up by the teachers showing their experiences about the impact of positive reinforcement impact on learners' performance.

Secondary level learners of Bahawalpur City were part of this study. The data were collected from $9^{\text {th }}$ grade learners in the academic year 2019-20.

In this study, fifty students and thirty teachers from Govt. S. D. High School, Bahawalpur, and Workers Welfare High School (Girls), Bahawalpur participated. Grade-9 learners were selected randomly. Among them, fifty students belonged to the control group, and fifty students' belonged to the experimental group. Each group had equal participation of male and female students.
Following tools were used to collect the data from the respondents: 1: Questionnaire for teachers.2: Pretest and Post-test for students.

The data were collected using a close-ended selfdeveloped questionnaire of 30 items with five main indicators subdivided into six indicators. The questionnaires were delivered to teachers about their teaching experiences. The test was used to collect the data to find out the impact of reinforcement from the respondents who were students. There were both open-ended and close-ended questions. Test and questionnaires were the research tools used for this study.

\section{Findings}

4.1. Is there an apparent distinction in male and female students' achievement scores under reinforcement and motivational tools in experimental and control groups?

Table 1. Comparison of Achievement Scores of Experimental and Control Groups

\begin{tabular}{lcccc}
\hline \hline & & & & \\
Respondents & $\mathrm{N}$ & Mean & $\mathrm{SD}$ & $\mathrm{t}$ \\
\hline $\begin{array}{c}\text { Control } \\
\text { Group }\end{array}$ & 50 & 50.35 & 10.21 & \\
$\begin{array}{c}\text { Experimental } \\
\text { Group }\end{array}$ & 50 & 55.62 & 11.35 & $-1.258^{*}$ \\
\hline \hline & & & & \\
\hline & & & & \\
& & & & \\
& & &
\end{tabular}

Table 1 discovered an apparent distinction in students' achievement scores between control and experimental groups under reinforcement and motivational tools. The two groups had an apparent distinction between them. The mean achievement score of the control group $(\mathrm{M}=50.35, \mathrm{sd}=10.21)$ and experimental group $(\mathrm{M}=55.62, \mathrm{sd}=11.35)$ with (p value $<0.05$ ) shows that the experimental group had a better achievement score as compared with the control group under reinforcement techniques. So the research question, "Is there an apparent distinction in control and experimental groups about students' performance under motivational tools?" answered positively.

\subsection{Is there an apparent distinction in male and female students' achievement scores under reinforcement and motivational tools in the experimental group?}

Table 2. Students' Performance in Experimental Group through Motivational Tools

\begin{tabular}{lllll}
\hline \hline Students & $\mathrm{N}$ & Mean & SD & $\mathbf{t}$ \\
\hline
\end{tabular}




$\begin{array}{ccccc}\text { Male } & 25 & 54.57 & 10.25 & \\ \text { Female } & 25 & 61.34 & 11.31 & .1 .342 * * \\ & & * * \mathrm{p}<0.01\end{array}$

In table 2, there was an apparent distinction in students' achievement scores between males and female. There is an apparent difference between the two types of groups. The achievement of male students $(M=54.57, \mathrm{sd}=10.25)$ and female students $(\mathrm{M}=61.34, \mathrm{sd}=11.31)$ with ( $\mathrm{p}$ value $<0.01)$ showed that female respondents achieved higher as compared with male respondents. So the research question, "Is there an apparent distinction in male and female students' achievement scores under reinforcement and motivational tools in the experimental group?" answered positive.

\subsection{Frequency analysis of reinforcement techniques in the English language classroom, overall mean achievement score, and standard deviation of motivational tools}

Table 3. Mean Score of Overall Learning through Motivational Tools Among the Learners

\begin{tabular}{cccccc}
\hline \hline & Praise & Reward Stickers & Star & $\begin{array}{c}\text { Thumbs } \\
\text { up }\end{array}$ \\
\hline Mean & 3.40 & 3.47 & 3.54 & 3.61 & 3.86 \\
Std. D. & 1.26 & 1.07 & .58 & 1.79 & 1.02 \\
\hline \hline & \multicolumn{6}{c}{$\mathrm{n}=50$}
\end{tabular}

It is evident from table 3 that the most useful motivational tool among the learners was the thumbsup technique. The second learning technique was a star for the students. The third learning technique was using stickers. A reward was the fourth important indicator for the learners at the school level. The last technique that was used for the students was praise.

4.4. Frequency analysis of reinforcement techniques for male students in an English language classroom, overall mean achievement score, and standard deviation of motivational tools

Table 4. Mean Score of Male Students Learning through Motivational Tools

\begin{tabular}{cccccc}
\hline \hline Tests & Praise & Reward & Stickers & Star & $\begin{array}{c}\text { Thumbs } \\
\text { up }\end{array}$ \\
\hline Mean & 3.28 & 3.54 & 3.38 & 3.80 & 3.45 \\
Std. D. & 1.15 & 1.53 & .52 & .59 & 1.21 \\
\hline \hline
\end{tabular}

$$
\mathrm{n}=25
$$

Table 4 illustrates that the most useful motivational technique among male learners was the star technique. The second learning technique was a reward for the students. The third learning technique was thumbs up. The fourth technique was using stickers. The last technique that the male students used was praise. It is evident from the bar graph below:

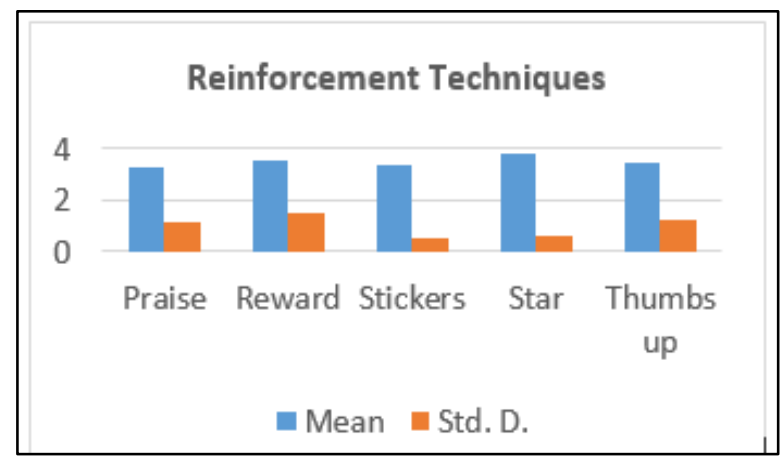

4.5. Frequency analysis of reinforcement techniques for female students in the English language classroom, overall mean achievement score, and standard deviation of motivational tools

Table 5. Mean Score of Female Students through Motivational Tools

\begin{tabular}{cccccc}
\hline \hline & Praise & Reward Stickers & Star & $\begin{array}{c}\text { Thumbs } \\
\text { up }\end{array}$ \\
\hline Mean & 4.42 & 3.80 & 4.31 & 3.90 & 4.55 \\
SD & 1.05 & .52 & .37 & .48 & .14 \\
\hline \hline \multicolumn{5}{c}{$\mathrm{N}=25$}
\end{tabular}

Table 5 demonstrates that the most useful learning technique among female learners was thumbs up. The second technique used by the female students was praise. The third technique was stickers. The fourth one was the star technique. The last technique used by female ESL students was a reward. It is evident from the bar graph below.

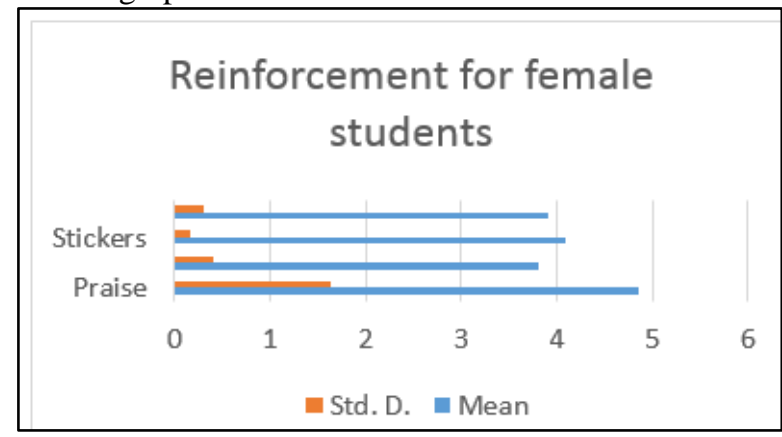

4.6. The perceptions of the teachers regarding the use of motivational Techniques

The perceptions of teachers revealed that when they provided their students' different techniques of 
reinforcement, their students engage more in learning the English language. These activities make them enthusiastic about language learning. According to the teacher, praise is the best technique for their encouragement. The second technique was stickers. The third technique was stars. In the last, they perceived that reward is also an incentive for improving their academic performance. It is evident in graph below.

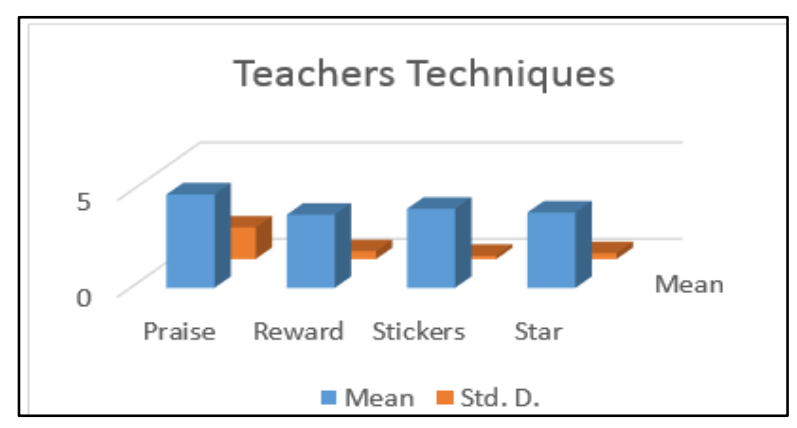

\section{Discussion}

A significant difference in students' performance between the control and experimental group under motivational tools was found. It was concluded that when motivational tools were applied in the form of reinforcement, the attitude of students towards language learning improved. The attitude developed in response to motivational techniques. The study is supported by the previous studies conducted by Oroujlou and Vahedi (2011). The mean achievement score of the control and experimental group shows that the experimental group had a better achievement score as compared with the control group. The study supported the prior studies, as suggested by Kim and Kim (2016), that demotivation is influenced by external factors related to learners. There was an apparent distinction in students' performance between males and females.

The achievement score of male students and female students shows that female students have performed better than male students. Meara and Fitzpatrick (2000) and Jimenez (2010) showed that females perform higher than males. Scarcella \& Zimmerman, 1998) showed that males are dominant over females' incomprehension. Many other studies conducted by Lin and Wu (2003), Lynn et al. (2005), and Edelenbos and Vinje (2000) investigated the superiority of males over females in getting knowledge of the foreign language. Male students incorporate more new words into lexicons than female students (Llach \& Gallego, 2012).

The overall most useful learning technique among the learners was the thumbs-up technique. The second learning technique was the star for the students. The third learning technique was using stickers. The reward was the fourth important indicator for the learners at the school level. According to Adara study (2018), missing intrinsic motivation is the prominent de-motivational factor among the learners. The last technique that was used for the students was praise. The most useful motivational technique among male learners was the star technique. The second learning technique was a reward for the students. The third learning technique was thumbs up. The fourth technique was using stickers.

The last technique that the male students used was praise. On the other hand, the most useful learning technique among female learners was thumbs up. The second technique used by the female students was praise. The third technique was stickers. The fourth one was the star technique. The last technique used by female ESL students was the reward.

\section{Conclusions}

The use of positive reinforcement through motivational tools is necessary for our English language classes. With the use of this technique, a positive change can be created among the students. A positive and healthy motivational environment is very necessary for long-term learning and achievement for the learners. With positive reinforcement, lesson plans can be improved, and students show more willingness and interest in their studies. With it, learning can be made more interesting and useful even for those students who are not good at their studies. Moreover, from the analysis and interpretation of the data, the researchers had found that:

1) The old and traditional ways of teaching were still applied in schools.

2) Teachers were not trained enough, and they were not ready to use new learning techniques in their classes.

3) Positive reinforcement is necessary for classrooms.

4) Motivational tools can bring desirable positive change among students.

5) Lack of positive reinforcement is visible from the lesson plans of teachers.

\section{Suggestions}

Following suggestions and recommendations were made:

1) English is an interesting subject so it should be taught with different activities and some motivational tools so that the students may develop their interest in it.

2) The behavior of the teachers should be positive and friendly with their students.

3) Teacher training workshops should be conducted.

4) In teaching English, four skills must be included with interesting activities. 
5) Use motivational tools should be used in the class appropriately.

6) More target language should be used during the lecture.

7) Teachers should use and adopt new and innovative learning strategies full of positive reinforcement in their classes.

8) The teacher should motivate the students to participate in the class on an equal basis.

\section{References}

Adara, R. A. (2018). Demotivating Factors of Indonesian College Students to Learn English as A Foreign Language. Sukma: Jurnal Pendidikan, 2(1), 1-24

Ahmad, Z., \& Mahmood, N. (2010). Effects of cooperative learning vs. traditional instruction on prospective teachers' learning experience and achievement. Ankara Üniversitesi Ĕ̈itim Bilimleri Fakültesi Dergisi, 43(1), 151-164.

Bahramy, M., \& Araghi, M. (2013). The identification of demotives in EFL university students. International Journal of Basic and Applied Science, 1(4), 840-845.

Cherry, K. (2021). Extrinsic Motivation. Retrieved on 24 Jan. 2021 from https://www. verywell mind .com/ what-is-extrinsic-motivation2795164

Christie, T., \& M. Afzaal (2005). Rote memorization as a sufficient explanation of secondary school examination achievement in Pakistan: An empirical investigation of a widespread assumption. A paper presented at an IAEA international conference entitled Assessment and the future schooling and learning held at Abuja, Nigeria September, 4-9.

Dörnyei, Z. (1998). Motivation in second and foreign language learning. Language teaching, 31(3), $117-135$

Dörnyei, Z., \& Ushioda, E. (2013). Teaching and researching: Motivation.

Dowaliby, F., \& Schumer, H. (1973). Teachercentered versus student-centered mode of college classroom instruction as related to manifest anxiety. Journal of Educational Psychology, 64(2), 125.

Edelenbos, P., \& Vinjé, M. P. (2000). The assessment of a foreign language at the end of primary (elementary) education. Language testing, 17(2), 144-162.

Evans, M., \& Tragant, E. (2020). Demotivation and Dropout in Adult EFL Learners. TESL-EJ, 23(4), n4.
Henderlong, J., \& Lepper, M. R. (2002). The effects of praise on children's intrinsic motivation: A review and synthesis. Psychological bulletin, $128(5), 774$.

Iqbal, A. S. I. F. (2010). A Comparative Study of The Impact of Principals' leadership Styles on The Job Satisfaction of Teachers. Doctoral dissertation. University of the Punjab Lahore.

Jiménez, R. M., \& Rosa, M. (2010). Gender perspectives on vocabulary in foreign and second language. Palgrave Macmillan UK

Khaliq, A., Douna, M. S. R., \& Ahsan, M. (2016). Role of Reinforcement or Punishment in Learning English Language: A Study at Secondary Level in Southern Punjab Pakistan. International Journal of Business and Social Science, 7(8), 137-146.

Kim, T. Y., Kim, Y., \& Kim, J. Y. (2018). A Qualitative Inquiry on EFL Learning Demotivation and Resilience: A Study of Primary and Secondary EFL Students in South Korea. Asia-Pacific Education Researcher, 27(1), 55-64.

Krishnan, K. S. D., \& Pathan, Z. H. (2013). Investigating demotivation in learning English: An extension to Sakai and Kikuchi's (2009) framework. Advances in Language and Literary Studies, 4(2), 124-131.

Larasati, F. (2018). Student Centered Learning: An Approach to Develop Speaking Skill in EFL Classroom. English Community Journal, 2(1), 153-157.

Leonard, N. H., Beauvais, L. L., \& Scholl, R. W. (1999). Work motivation: The incorporation of self-concept-based processes. Human relations, 52(8), 969-998.

Lin, J., \& Wu, F. (2004). Differential Performance by Gender in Foreign Language Testing.

Llach, M. P. A., \& Gallego, M. T. (2012). Vocabulary knowledge development and gender differences in a second language. Elia, 12(1), 45-75.

Lynn, R., Fergusson, D. M., \& Horwood, L. J. (2005). Sex differences on the WISC-R in New Zealand. Personality and Individual Differences, 39(1), 103-114.

Meara, P., \& Fitzpatrick, T. (2000). Lex30: An improved method of assessing productive vocabulary in an L2. System, 28(1), 19-30.

Ng, C. F., \& Ng, P. K. (2015). A review of intrinsic and extrinsic motivations of ESL learners. International Journal of Languages, Literature and Linguistics, 1(2), 98-105. 
Oroujlou, N., \& Vahedi, M. (2011). Motivation, attitude, and language learning. Procedia-Social and Behavioral Sciences, 29, 994-1000.

Oxford, R., \& Shearin, J. (1994). Language Learning Motivation: Expanding the theoretical framework. The modern language journal, 78(1), 12-28.

Pratiwi, M. A., Sudirman, S., \& Adnyani, L. S. (2018). A Study of the Reinforcement Used By English Teacher in 6a Class at SD Lab Undiksha Singaraja. International Journal of Language and Literature, 2(3), 117-124.

Rachman, D., \& Nur, D. R. (2017). The Relationship between English Teacher's Praise and English Learning Achievement of The Tenth Grade of SMK Negeri 9 Samarinda. JELE (Journal of English Language and Education), 3(1), 54-62.

Sahana, 2012. Six Common Reasons for lack of motivation. Retrieved from: http://w.w.w.sysahana.org/2012/04/ SixCommon reasons-for-lack-of-motivation.

Scarcella, R., \& Zimmerman, C. (1998). Academic Words and Gender: ESL Student Performance on a Test of Academic Lexicon. Studies in Second Language Acquisition, 20(1), 27-49. Retrieved February 18, 2021, from http://www.jstor.org/stable/44486382

Tanaka, M. (2017). Examining EFL vocabulary learning motivation in a demotivating learning environment. System, 65, 130-138.

Vibulphol, J. (2016). Students' Motivation and Learning and Teachers' Motivational Strategies in English Classrooms in Thailand. English Language Teaching, 9(4), 64-75. 